\title{
Teratodermoid cyst of the mediastinum with pancreatic enzyme secretion
}

\author{
J SOUTHGATE, PR SLADE
}

From the Departments of Pathology and Thoracic Surgery, Groby Road Hospital, Leicester

At operation dermoid cysts of the mediastinum are frequently found to be densely adherent to surrounding structures and often apparently invading them. This tendency is often attributed to infection, ${ }^{1}$ though positive cultures from the cyst contents have seldom been obtained. An alternative explanation may be that these characteristics are due to proteolytic enzymes produced in the cyst. A case is reported that would appear to support the latter hypothesis.

\section{Case report}

A 16-year-old girl complained of a pleuritic type of pain, of about four weeks duration, in the axillary region of the right chest. The only abnormality noted on physical examination was dullness to percussion and reduced air entry over the front of the upper part of the right chest.

A chest radiograph (fig 1) showed an opacity in the anterior upper mediastinum and tomography showed calcification within the opacity. A postero-anterior chest radiograph had been taken six years previously. This was reviewed and appeared to be within normal limits.

Right thoracotomy was performed through an anterolateral fourth rib bed incision. There was a mass occupying the anterior mediastinum and bulging into the right pleural cavity, which was adherent to the thymus, the left pleural sac, and a wide area of the pericardium. The phrenic nerve was stretched over the base of the mass, but could be dissected away from it. The middle lobe of the lung was consolidated and intimately attached to the mass, which was excised with the middle lobe of the lung, the thymus, and a large portion of the pericardium. The defect in the pericardium was closed with a pleural patch. The patient made an uneventful recovery from the operation and is well more than a year later.

Examination of the operation specimen showed a cystic mass, measuring $11 \times 7 \times 6.5 \mathrm{~cm}$ in the fixed state. Some of the cystic spaces contained sebaceous material and had hair-bearing areas; others contained brown-coloured fluid. There was a central bony plate around which were arranged cystic areas. Histological examination showed tissues derived from all three germinal layers. In the wall of some of the cysts there was glandular pancreatic tissue together with an adenomatous islet-cell type of tissue (fig 2).

The middle lobe of the lung was consolidated, with necrotic cystic areas in its substance. On histological examination, there was extensive inflammatory cell exudation into

Address for reprint requests: Dr J Southgate, Groby Road Hospital, Groby Road, Leicester LE3 9QE.

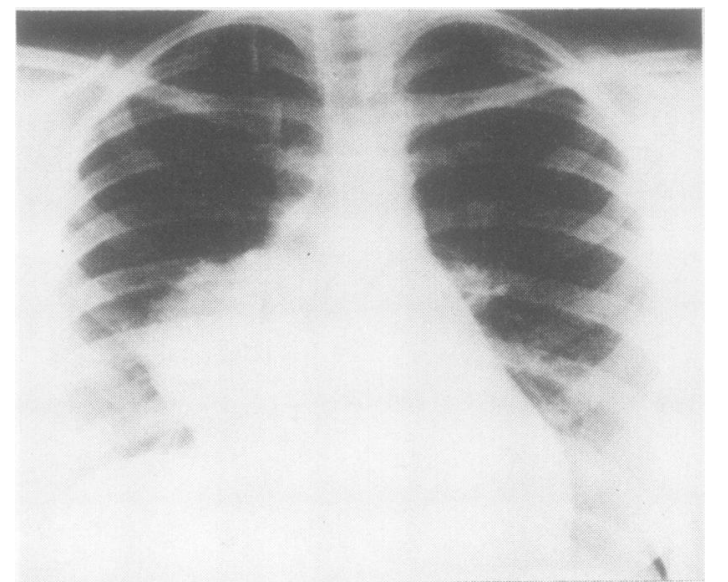

Fig 1 Chest radiograph taken at onset of symptoms.

the alveolar spaces. Fluid from the cysts in the mass was examined immediately after removal and before fixation. The fluid was sterile on culture. Fluid from two of the cysts had an amylase activity of $170 \mathrm{U} / \mathrm{l}$, but the fluid from a third showed an activity of $1120 \mathrm{U} / \mathrm{l}$.

\section{Discussion}

Erosion of mediastinal teratoids into surrounding structures has been well documented. Le Roux, ${ }^{2}$ in a series of 19 cases, reported two patients who coughed up sebaceous material. Galy et $a^{3}{ }^{3}$ recorded three cases of fistula into the bronchial tree. Marsten et $\mathrm{al}^{4}$ described cardiac tamponade due to erosion of a mediastinal dermoid into the pericardial cavity.

We have recently studied six cases of mediastinal dermoids treated surgically. ${ }^{5}$ In these cases only those teratoids that contained a glandular secretory type of tissue, and particularly pancreatic tissue, were adherent to and eroding into the adjacent tissues. Cysts containing only ectodermal structures were free of adhesions.

Sommerlad et $\mathrm{al}^{6}$ have reported a case in which a persistent fistula followed biopsy of a mediastinal mass by cervical mediastinoscopy. Fluid from the fistula had an amylase activity of 8000 Somogyi units/l. At operation the mass was found to be a teratodermoid. Apart from this case, however, fluid from the cysts in mediastinal dermoids does not seem to have been examined for enzyme activity.

Interestingly, the patient reported here had an apparently normal chest radiograph only six years previously. 


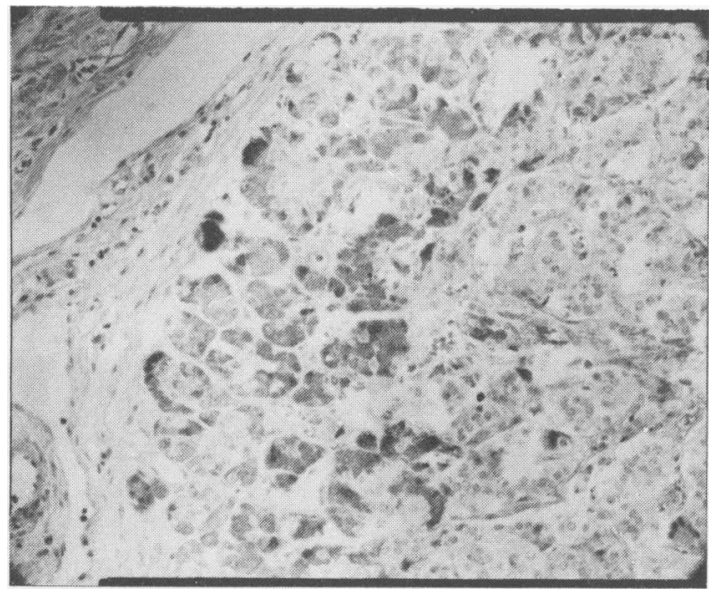

Fig 2 Section showing pancreatic tissue with centroacinar cells and closely adjacent islet-cell type of tissue

(Picro-Mallory stain, $\times 400)$.

Enlargement of mediastinal teratoids may occur during the growth period, but probably the acute symptoms and large, radiographic shadowing were due to erosion into the lung.

We would like to thank Miss J Morcomb for the biochemical investigation, $\mathrm{Mr} \mathrm{J}$ Grenfell for the photographic reproductions, and Miss $\mathrm{J}$ Ridgway for editorial and secretarial assistance.

\section{References}

${ }^{1}$ Korolev BA, Korepanova HB, Szabaiev HG. Teratodermoids of mediastinum. Khriurgia (Mosk) 1978;8:104-6.

${ }^{2}$ Le Roux BT. Mediastinal teratoma. Thorax 1960;15:333-8.

${ }^{3}$ Galy P, Brune J, Dorsit G, Russet H, Seigneuric A, Porte J. Trois cas de kystes dermoids du mediastin fistulisés dans les bronches. Lyon Médical 1971;226:389-91.

4 Marsten JL, Cooper AG, Ankeney JL. Acute cardiac tamponade due to rupture of a benign mediastinal teratoma into the pericardial sac. J Thorac Cardiovasc Surg 1966;51:700-6.

s Southgate J, Slade PR. Dermoid cysts of the mediastinum. Thorax 1980;35: 222.

' Sommerlad BC, Cleland WP, Young NK. Physiological activity in mediastinal teratomata. Thorax 1975;30:510-5. 